\title{
K REDEFINICI VYBRANÝCH POJMŮ VE ŠPANĚLSKÉ TRANSLATOLOGII OPTIKOU PRACÍ JIŘíHO LEVÉHO'
}

\author{
JANA KRÁLOVÁ
}

\begin{abstract}
This paper aims to present a comparison between some concepts authored by contemporary Spanish translation scholars and the ideas formulated by Jiř́ Levý. A short outline of the evolution of Translation Studies in Spanish speaking countries in the second half of the 20th century is taken as a basis for the explanation of the lack of awareness of Levýs theories among the Spanish speaking authors. Compared to some recent concepts studied in Spanish (the so-called anisomorfisms in translation, the problem of the source of the translating activity), the concepts attributed to Jiří Levý (translation as a decision process, the source) seem to be more dynamic and complex. Therefore, Levýs theories can be considered as methodologically innovative, despite having been defined more than fifty years ago.
\end{abstract}

Key words: Translation Studies evolution, anismomorfism, descision process, source, methodological innovation

\section{Úvodní poznámky}

V souvislosti se snahou po metodologické inovaci translatologie (např. Vidal Claramonte 2009; Lambert 2010; Jordà Mathiasen 2016) se do centra pozornosti badatelů znovu dostávají pojmy a koncepce, které byly donedávna považovány za okrajové, př́padně klasické nebo zastaralé. Cílem tohoto př́íspěvku je poukázat na vybrané pojmy a teoretické konstrukty, které se $\mathrm{v}$ posledních letech opakovaně objevují v pracích španělsky píśících badatelů, a srovnat je s koncepty, které již před více než padesáti lety prosazoval ve svých pracích Jiří Levý.

Analýzu vztahu Levého koncepce a hispánského jazykového prostředí lze na druhé straně považovat za určitou „případovou studii“2, zejména bereme-li v úvahu, že obě tradice stály dlouhou dobu stranou pozornosti odborné veřejnosti, a to i přes fakt, že samotné překládání a tlumočení má jak ve Španělsku a v Latinské Americe, tak v českém prostředí staletou tradici a jeho dějiny jsou předmětem dlouhodobého zkoumání. Pro

1 Tato studie vznikla za podpory projektu Univerzity Karlovy Progres Q 10, Jazyk v proměnách času, místa, kultury.

2 Obecné aspekty recepce díla J. Levého ve Španělsku a v Latinské Americe jsou tématem samostatného př́spěvku v tomto čísle Translatologica Pragensia. 
španělskou jazykovou oblast můžeme jako příklad uvést Santoyovu monografii (Santoyo 2011), zabývající se překladem na Pyrenejském poloostrově od třetího do konce patnáctého století, ${ }^{3}$ pro českou kulturu pak zejména Levého práci České theorie prekladu (Levý, 1957), která mj. představuje zřejmě první antologii prací zaměřených na teoretickou reflexi překladu v evropském kulturním kontextu. Dalším nesporným faktem je skutečnost, že dobývání Ameriky a její kolonizace přinesly nejen nové požadavky na překládání/tlumočení, ale i další diverzifikaci nejrůznějších typů mezikulturní komunikace, a tedy i témat aktuálních nejen pro soudobé bádání, jako např. význam empirického základu a práce s prameny, analýza role peritextů, uvádění nových pojmů do translatologických bádání, případně redefinice pojmů tradičních (tzv. kulturní překlad, překlad bez textualizovaného originálu, osobnost překladatele, intersémiotický překlad, překlad a gender apod.). ${ }^{4}$

Dynamika vývoje translatologie v moderním pojetí v hispánské jazykové a kulturní oblasti v posledních desetiletích vynikne, zejména pokud si uvědomíme, že až do poloviny sedmdesátých let dvacátého století bylo Španělsko „pustinou“ v bádání o překladu a tlumočení: studie, reference i centra pro studium této disciplíny prakticky neexistovaly (Santoyo 2012, citováno podle Sabio Pinilla 2017: 310). Práce v současné době považované za zakladatelské jsou pro španělské prostředí spjaté s osobností Valentína Garcíi Yebry ${ }^{5}$ a vznikaly až v polovině osmdesátých let dvacátého století (Sabio Pinilla 2017: 310). Do té doby převládalo ve Španělsku filologicko-lingvistické pojetí překladu, vycházející zejména z překládání z klasických jazyků (Sabio Pinilla 2017: 314-315): na jedné straně byl překlad považován za prostředek pro výuku jazyků, na druhé straně bylo jeho zkoumání soustředěno výhradně na literární překlad. Od poloviny padesátých let se však začaly objevovat první hlasy, které požadovaly potřebu vzdělávat překladatele, a překonávat tak propast mezi akademickým prostředím a výkonem překladatelské profese (Sabio Pinilla 2017: 313).

Od poloviny osmdesátých let dochází k zakládání vysokého počtu vysokoškolských pracovišt', zaměřených na výchovu překladatelů a tlumočníkůa a s tím související rozvoj a diversifikace badatelské práce v oboru. Zároveň vzniká řada translatologických časopisů, o jejichž kvalitě svědčí zařazení do světových databázi (SCOPUS, WOS) ${ }^{6}$ i např. zastoupení hispánských (španělských a latinskoamerických) autorů a témat v časopise META, jednom z nejvýznamnějších translatologických médií s dlouhou tradicí vydávání řady citovaných monografií a dalších publikací (Sabio Pinilla 2017).

Obdobného vývoje jsme svědky i v Latinské Americe (Vavroušová et al. 2015). I když jde tedy o areál, který se v translatologii také jeví jako poměrně nový, ${ }^{7} \mathrm{v}$ posledních

3 Už v 15. století vznikl ve Španělsku první překladatelský metajazyk (Santoyo, 2008, 88-102; v češtině Vavroušová et al. 2013: 19-37).

4 Podrobněji k této problematice Králová 2018.

5 Sabio Pinilla (2017) cituje v této souvislosti následující práce Valentína Garcíi Yebry: Teoría y práctica de la traducción (1981); En torno a la traducción (1983); 'À propos de mes traductions', Meta 38(4), (1993), pp. 621-629; Traducción: historia y teoría (1994); El buen uso de las palabras (2003); Traducción y enriquecimiento de la lengua del traductor (2004); Experiencias de un traductor (2006).

6 Např. časopis Sendebar, vydávaný Univerzitou v Granadě, Monográficas de Traducción e Interpretación (MonTI), vydávaný Univerzitou v Alicante; Herméneus, vydávaný Univerzitou ve Valladolidu, se sídlem v Sorii, Quaderns: revista de traducció, vydávaná Autonomní univerzitou v Barceloně.

7 Latinskoameričtí badatelé se jako k zakladatelské hlásí k práci Geralda Vázqueze Ayory Introducción a la traductología, vydané v r. 1977 v USA (např̀. Venegas Piracón, 2017). K recepci latinskoamerické translatologie v českém badatelském prostředí Králová (2017). 
desetiletích zažívá výrazný rozvoj a s ním souvisí rovněž tendence k metodologické diversifikaci oboru, jeho tematickému obohacení, a to v souvislosti se studiem vlastních kultur a s nimi souvisejícími snahami po novém definování vybraných „zavedených“ konceptů.

Recepce díla J. Levého ve Španělsku a v Latinské Americe představuje samostatné badatelské téma, i když i na oblast zkoumání překladu lze aplikovat konstatování J. C. Santoya (2011: 1984) o dluhu, který má španělská historie překladu vůči slovanským literaturám a kulturám.

Cílem tohoto příspěvku je proto na příkladu dvou v současnosti stále aktuálních otázek, které si španělská i latinskoamerická translatologie opakovaně kladou, poukázat na koincidence s koncepty, které se před více než padesáti lety objevovaly v pracích J. Levého, a to s důrazem zejména na dva tematické okruhy: otázku volby překladatelských řešení a pojetí východiska práce překladatele.

\section{Volba překladatelských řešení}

Otázka volby překladatelských řešení a jejích případných omezení se v současné španělské translatologii objevuje opakovaně (např. Ortiz García, 2002; Vidal Claramonte, 2009; Franco Aixelá, 2016; Jordà Mathiasen, E., 2016). Autoři se shodují v tom, že při tvorbě cílového textu "překladatel nemůže než přijmout roli manipulátora"8 (Jordà Mathiassen, 2016: 132). Jako bezprostř̌ední východisko pro porovnání soudobé španělské koncepce analýzy volby překladatelských řešení a pojetí J. Levého byla zvolena studie J. Franka Aixelá (2016), v níž autor definuje tzv. anizomorfismy v překladu.

\subsection{Pojem anizomorfismu v překladu}

Javier Franco Aixelá (2016) vychází z analýzy překladu jako produktu a na tomto základě definuje čtyři typy tzv. anizomorfismů (J. Franco Aixelá 2016: 199): jazykové, interpretační, pragmatické a kulturní. V konkrétních příkladech vychází z jazykové a kulturní dvojice angličtina-španělština, ale jeho koncepce je aplikovatelná i na další pracovní jazyky.

Při analýze jazykových anizomorfismů vychází z asymetrií jazykových systémů zejména na základě Jakobsonova pojetí rozdílů mezi pracovními jazyky. Upozorňuje především na skutečnost, že jazyky se vedle roviny lexikální a frazeologické liší rovněž na rovině morfologické a syntaktické, že jednotlivé jednotky daného jazyka nelze analyzovat bez zřetele $\mathrm{k}$ dalším prvkům daného jazykového systému i k dané kultuře a v neposlední řadě $\mathrm{k}$ mluvčímu. $\mathrm{V}$ oblasti lexika pak upozorňuje na úskalí vyplývající ze ztotožnění určitého pojmenování s jeho „prvoplánovým“ respondentem v překladovém slovníku. Ve svém výkladu vedle Jakobsona upozorňuje na humboldtovské tradice, Sapira-Whorfa a opírá rovněž o Mounina. ${ }^{9}$

8 "Al traductor no le queda otro remedio que asumir su papel de [...] manipulador."

9 Není jistě bez zajímavosti, že první vydání Mouninových Teoretických problémů překladu bylo vydáno ve stejném roce jako Levého Umění překladu, tedy v roce 1963. Jak připomíná Navarro (2011: 24), jejich překlad byl pořízen téměř bezprostředně po vydání francouzského originálu. 
Pojem tzv. interpretačního anizomorfismu vychází podle J. Franka z faktu, že význam textu není uzavřený. Při jeho analýze vychází nejen z pojetí o tradičních španělských autorit, (zejména o texty zmíněného Valentína Garcíi Yebry), ale klade důraz také na teorii Scoposu, především na konstatování, že text originálu představuje otevřenou nabídku informace, z níž každý vybírá podle svých preferencí, podle svých schopností text pochopit i podle svého idiolektu. Překlad tedy nemůže být totožný s originálem z toho důvodu, že neexistuje jediný originál s uzavřeným významem, s nímž by mohl být překlad identický (srov. též Jordà Mathiasen 2016: 132).

V oddíle věnovaném pragmatickému anizomorfismu autor zdůrazňuje zejména rozdílné žánrové konvence pro vyjádření téhož sdělení v různých kulturách, a to jak při tzv. homologickém překladu (formální kopie textu originálu), tak při tzv. překladu analogickém (funkční adaptace daného prostředku v textu překladu) může mít za následek výrazné formální a funkční rozdíly (Franco Aixelá 2016: 209) mezi textem originálu a textem překladu. Jako konkrétní příklad volí charakteristické rysy anglické eseje a problémy, které přináší vysoká frekvence slovesa být při překladu do španělštiny (zajímavé je, že relativně vysoký výskyt sloves být $\mathrm{v}$ původním španělském textu může rovněž působit problémy v nejen literárních př̀kladech ze španělštiny do češtiny).

Při nástinu anizomorfismů kulturních vybírá Javier Franco specifické kulturní jevy, jejich konotace a důsledky pro překlad. Př́klady volí zejména $\mathrm{z}$ oblasti politiky a gastronomie, upozorňuje i na aluze na významné osobnosti a místa, měrné jednotky specifické pro kulturu a popis zvyklostí cizích kultuře cílové.

\subsection{Překlad jako rozhodovací proces podle Levého}

Základním východiskem Levého koncepce je pojetí překladu jako komunikace, jejímž cílem je sdělování, a v návaznosti na to jeho definice překladatelského procesu jako zřetězení výběrů z určitého počtu alternativ (Levý 1967; 1971). Nelze pominout skutečnost, že zahraniční badatelé, pokud Levého v této souvislosti citují, vycházejí téměř výhradně $\mathrm{z}$ anglické studie zaměřené na překlad jako rozhodovací procesu (Levý, 1967) a ze současného hlediska hodnotí Levého pojetí mj. jako předchůdce kognitivismu ve zkoumání překladu (Bolaños 2016: 240).

Při porovnání obou koncepcí je nezbytné brát v úvahu skutečnost, že anglicky psaná studie je stručnější než česká verze, a je-li tedy vzata jako východisko pro analýzu Levého pojetí překladu jako rozhodovacího procesu (Levý 1967), vede zřejmě latinskoamerické badatele k závěru, že je Levý řazen spíše mezi autory lingvistického, nikoli literárněvědného a kulturního zaměření (Venegas Piracón 2017: 265), a to na rozdíl od kontextu bádání španělských (Vega Cernuda 2011: 18; 2013: 15).

$\mathrm{V}$ úplnosti je však pojetí překladu jako rozhodovacího procesu uvedeno ve studii ,Geneze a recepce literárního díla' (Levý 1971) ${ }^{10}$, kde je překlad chápán jako nepřetržitý výběr z řady alternativ, jehož základem je vymezení paradigmat prostředků obou pracovních jazyků na základě tzv. definiční instrukce, na niž pak navazují tzv. instrukce selektivní, dané:

10 Anglická verze Králová-Jettmarová (eds.) 2008: 47-88; částečná španělská verze Králová-Cuenca 2013: 119-142. 
a) kontextem (instrukce objektivní),

b) strukturou lingvistické paměti překladatele (instrukce subjektivní),

c) dobovou estetickou normou (instrukce intersubjektivní).

O aktuálnosti Levého pojetí překladu jako zřetězení výběrů z alternativních řešení svědčí také fakt, že se stále objevuje v řadě prací (např. Aurová 2016; Obdržálková 2016; Stefaniak 2017: 116), a to i mimo oblast literárního překladu.

\subsection{Anizomorfismy v překladu z hlediska překladu jako rozhodovacího procesu}

Na první pohled je jasné, že existuje jasná koincidence mezi tím, co Franco nazývá jazykovým anizomorfismem, a Levého vymezováním paradigmat v souladu s definičními instrukcemi: oba autoři pro ilustraci své koncepce vycházejí zejména z jednotek lexikálních a frazeologických, ale jak Levý, tak Franco upozorňují na skutečnost, že rozdíly se objevují i v dalších jazykových jednotkách. Levý však poukazuje na možnou volbu z alternativ i v oblasti utváření výpovědí (slovosledu), tedy složky vyjadřování, kterou Franco ponechává stranou (nově pro jazykovou dvojici španělština-čeština, srov. Aurová, 2016).

Analogie se nabízejí rovněž u Francova anizomorfismu interpretačního a druhou selektivní instrukcí Levého: s vědomím struktury překladatelovy lingvistické paměti překonává Levý určitou omezenost redukce „prvoplánových řešeni“ na problematiku překladových slovníků (Franco Aixelá 2016: 106). Není zde tedy jen patrné, že při definování tohoto anizomorfismu Franco nemůže zcela abstrahovat oproti svému formulovanému východisku od osobnosti překladatele, ale zejména skutečnost, že tím, že Levý postavil překladatele do centra svého výkladu, dospěl zřejmě k hlubším a přesvědčivějším závěrům než španělský autor, který často setrvává pouze u obecných konstatování. Ostatně interpretaci předlohy věnuje Levý i samostatný oddíl ve svém nejčastěji citovaném díle Umění překladu (2013: 56-63), nelze však ani zapomínat na skutečnost, že Levý nevidí překlad v jakémsi vzduchoprázdnu, ale upozorňuje na skutečnost (např. 1971: 71), že při analýze jakéhokoli díla/textu nelze rezignovat na to, co bylo před textem a co po něm následuje.

Relevance prrístupu J. Levého se projevuje i při analýzu jevu, o kterém Franco Aixelá hovoří jako o anizomorfismu pragmatickém. Nabízí se zde navíc souvislost s dalším pojmem J. Levého, a to s rolí kontextu jako druhé selektivní instrukce. Levý (1971: 89) si totiž klade otázky po funkci určitého stylistického principu v každém z pracovních jazyků, vztahu jazykové normy a stylu v různých typech literatury (textů) a v neposlední řadě i po složení čtenářstva, a tak předjímá celou řadu aspektů, které do svého pragmatického anizomorfismu zahrnuje Franco.

Posledním anizomorfismem, na nějž upozorňuje Franco, je anizomorfismus kulturní. Je zajímavé, že oba autoři uvádějí analogické příklady (vlastní jména, potraviny, zvyky apod.). V porovnání s Levého pojetím dobové estetické normy jako selektivní intersubjektivní instrukce vyniká statičnost Francova výkladu, a to i v obecné rovině: i když španělský autor konstatuje, že každé jazykové společenství má svoje zvyky, hodnotové škály apod., neklade na rozdíl od Levého důraz jejich dobovou, sociální a kulturní podmíněnost. 


\section{Východisko práce překladatele}

Otázka východiska práce překladatele představuje jedno z opakujících se témat ve španělském myšlení o překladu: jak připomíná např. Ortiz (2002: 1-4), opakovaně se objevuje negativní hodnocení binárních pojmů jako např́klad originál vs. překlad, autor vs. prrekladatel, model vs. kopie apod. V hispánské translatologii nabyl tento problém na významu zejména $\mathrm{v}$ souvislosti s rozšiřováním témat, na něž se $\mathrm{v}$ zhruba od počátku tohoto tisíciletí jeden směr translatologického bádání $v$ hispánské oblasti zaměřuje: role překladu/tlumočení při dobývání nových území, šíření španělské kultury i konstituování mimoevropských, zejména latinskoamerických kultur (Vega Cernuda 2012: 48).

Badatelé se zde setkávají se specifickými typy translace se silnou složkou socioantropologickou a estetickou, která výrazně přesahuje pojetí překladu jako prostého převodu mezi dvěma jazyky s respektem $\mathrm{k}$ cílové kultuře: jako typický př́klad lze uvést převod $\mathrm{z}$ mluvené podoby $\mathrm{v}$ domorodém jazyce do písemné podoby ve španělštině, tedy s jakýmsi „tlumočením z listu naruby“. ${ }^{11}$ Pro tuto formu mezikulturní komunikace volí autoři pojmenování „kulturní překlad“ (Pulido Correa 2015: 150; Martino Alba 2015: 8).

Dalším specifickým rysem převodu při konstituování mimoevropských kultur byla skutečnost, že text $\mathrm{v}$ původním jazyce není často písemně fixován, proto hledají badatelé $\mathrm{v}$ této oblasti termín, jak východisko práce překladatele pojmenovat, a hovoří $o$ překladu bez textualizovaného originálu (traducción sin original textualizado, Vega Cernuda 2012).

Variability/mnohotvárnosti východiska práce překladatele si byl vědom i Jiří Levý, není tedy náhodou, že v této souvislosti pracuje mj. s pojmem předloha, a tím do značné míry předjímá nejen budoucí vývoj zkoumání, ale i rozšiřování a tematickou diverzifikaci jeho předmětu (např. 1957 [1996], I: 233): „Vývoj reprodukčních, a tedy překladatelských metod je možno charakterizovat změnami ve vztahu $k$ předloze a ke čtenáři.“ (kurzíva J. K.)

Pojetí východiska práce překladatele jako předlohy lze tedy považovat $z$ hlediska vývoje translatologie, jejích metod i tematického rozrůznění za klíčový pro uchopení dynamiky této vědní disciplíny a aplikovatelný na rozšiřující se oblasti bádání, a to jak z hlediska tematického, tak geografického (srov. např. Jordà Mathiasen 2016: 123).

\section{Závěrečné poznámky}

Na základě uvedených zjištění je možné konstatovat, že řada témat, jimiž se zabýval před více než padesáti lety Jiří Levý, rozhodně nestojí přinejmenším v některých translatologických koncepcích stranou pozornosti ani v současnosti.

Položíme-li si otázku po příčině tohoto jevu, vedle jazyka, jímž je většina Levého prací napsána, a historických a politických souvislostí se jako nezanedbatelný jeví rovněž časový faktor. Stručný nástin vývoje překladatelských bádání v hispánské jazykové a kulturní oblasti lze považovat za částečné vysvětlení faktu, proč se španělská a latinskoamerická translatologie časově „míjela" $s$ pracemi Jiř́ho Levého. Vedle malé jazykové dostupnosti ${ }^{12}$ a dalších zmíněných činitelů zde zřejmě spolupůsobí i obecnější skutečnost a to, že Levé-

11 Osobní diskuse s P. Mračkovou Vavroušovou.

12 Výjimku př̀edstavuje Vega Cernuda (1994), vycházející z německé verze. 
ho práce „nezapadají do chronologické linie západních paradigmatických obratů, protože je poněkud předstihl jak teoreticky, tak metodologicky“ (Jettmarová, 2016: 7), a řada pojmů, koncepcí a konstruktů, jimiž se už před více než padesáti letý Jiří Levý zabýval, se ve Španělsku a v Latinské Americe znovu stává předmětem zkoumání i vědeckých diskusí teprve v posledních desetiletích, tedy řadu let po Levého smrti (Venegas Pinilla 2017: 265).

\section{BIBLIOGRAFIE}

Aurová, Miroslava (2016) 'La perspekctiva funcional de la oración en la traducción: Paradigmas es instrucciones selectivas'. Mutatis mutandis, 9(2): 283-400.

Bolaños Cuéllar, Sergio (2016) Introducción a la traductología: Autores, textos y comentarios, Bogotá D. C.: Editorial Universidad Nacional, 209-246.

Franco Aixelà, Javier (2016) 'Los anisomorfismos en la traducción', in Departamento de Traducción e intepretación (ed.) Una vida entre los libros, Alicante, Universidad de Alicante, 199-212.

Jordà Mathiasen, Eivor (2016) 'La equivalencia incalculable: el concepto de equivalencia traductora desde la deconstrucción', Herméneus 18, 119-137.

Králová, Jana and Miguel José Cuenca Drouhard (2013) Jiř́ levý: Una concepción redescubierta. Monográficos de la revista Herméneus 15. Soria: Vertere.

Králová, Jana and Zuzana Jettmarová et al. (2008) Tradition vs. modernity: From the classic period of the Prague School to translation studies at the beginning of the 21st century, Praha: Univerzita Karlova v Praze a TOGGA.

Králová, Jana and Zuzana Jettmarová (2010) 'Historia de la traducción: Fuente de inspiración', in Juan José Lanero, José Luis Chamoza (eds.) Lengua, traducción, recepción. En honor de J. C. Santoyo, II, León: Universidad de León, 373-394.

Králová, Jana (2016) 'El factor temporal en la evaluación de las teorías de la traducción', in Departamento de Traducción e intepretación (ed.) Una vida entre los libros, Alicante: Universidad de Alicante, 183-198.

Králová, Jana (2017) 'La recepción de la traductología latinoamericana en Chequia: inspiraciones temáticas, metodológicas y didácticas', Arts \& Humanitas, 11(2): 44-55.

Králová, Jana (2018) 'La traducción monacal desde la óptica de la traductología actual' (v tisku)

Lambert, José (2010) 'The Languages of Translation. Keys to the Dynamics of Culture', in Micaela Muñoz-Calvo, Carmen Gómez Buesa (eds.) Translation and Cultural Indentity: Selected Essays on Translation and Cross-Cultural Communication, New Castle: Cambridge Scholars publishing, 33-60.

Levý, Jiří (1957) České theorie prekladu. Praha: SNKLHU

Levý, Jiří (1963 [2013]) Umění prekladu. Praha: Československý spisovatel.

Levý, Jiři (1967) 'Translation as a decision process', in To Honor Roman Jakobson: Essays on the Occasion of His Seventieth Birthday, II, The Hague: Mouton, 1967, 1171-1182.

Levý, Jiř́ (1971) Bude literární věda exaktní vědou?, Praha: Československý spisovatel.

Martino Alba, Pilar (2015) 'Las aportaciones lingüísticas y literarias de fray Domingo de Santo Tomás, O. P.: de la traducción sin original textualizado a las fuentes documentales', Mutatis Mutandis 8(1): 8-27.

Navarro Domínguez, Fernando (2011) 'Jiří Levý: la teoría de la traducción y la lingüística', Ibero-america Pragensia - Supplementum 27: 21-31.

Ortiza García, Javier (2002) 'Traducción y posmodernidad: una relacon necesaria', Hermēneus 4: 129-145.

Obdržálková, Vanda (2016) 'Translation as a decision-making process: an application of the model proposed by Jiř́ Levý to translation into a non-mother tongue. Mutatis mutandis, 9(2): 306-327: https:// dialnet.unirioja.es/servlet/articulo?codigo=5759986 (access: 21. 9. 2017).

Pulido Correa, Martha (2015) 'El Catecismo (1576) de Fray Luis Zapata de Cárdenas, traducción cultural: tentativa de comprensión de la historia cultural y religiosa de Colombia', Mutatis Mutandisl 8,1. 
148-162; přetištěno v Miguel Angel Vega Cernuda, Martha Lucía Pulido Correa (eds.) (2016) El escrito misionero como mediación intercultural de carácter multidisciplinar, Madrid: Ommpress, 149-163.

Sabio Pinilla, José Antonio (2017) 'El legado de los filólogos a la traducción: Valentín García Yebra', Herméneus 19: 309-334.

Santoyo, Julio César (2008) Historia de la traducción: viejos y nuevos apuntes. León: Universidad de León. Santoyo, Julio César (2011) 'Iberian Translation History: whan we know and what we do not know', in Harald Kittel, Armin Paul Frank, Norbert Greinerm, Theo Hermans, Werner Koller, José Lambert, Fritz Paul (eds.) Übersetzung Translation Traduction. Berlin - Boston: Walter de Gruyter, 1981-1984.

Santoyo, Julio César (2009) La traducción medieval en la Península Ibérica (siglos III-XV), León: Universidad de León.

Stefaniak, Karolina (2017) 'Terminology work in the European Comission: Ensuring high quality translation in a mulitiligual environtemnt', in Tomáš Svoboda, Lucja Biel, Krysztov Loboda (eds.) Quality aspects in intestitutiona translation, Berlin: Freie Universität Berlin, 109-123.

Vavroušová, Petra (ed.) (2015) Překlad a tlumočení jako most mezi kulturami. Praha: Karolinum.

Vavroušová, Petra (ed.) (2013) Sedm tvář́ translatologie. Praha: Karolinum.

Vega Cernuda, Miguel Ángel (2011) 'El Caso Levý: Fenomenología de du recepción y valoración de sus aportaciones en el contexto de la traductología de la época', Ibero-americana Pragensia - Supplementum 27: 11-20.

Vega Cernuda, Miguel Ángel (1994, 2004). Textos clásicos de teoría de la traducción, Madrid, Cátedra.

Vega Cernuda, Miguel Angel (2012) Traductores hispanos en la orden franciscana en Hispanoamérica, Lima: Unversidad Ricardo Palma.

Venegas Piracón, L. E. (2017) 'Reseña de libro: Introducción a la traductología: Autores, textos y comentarios, Sergio Bolaños Cuéllar, Editorial Universidad Nacional, Bogotá D. C. 2016', Mutatis Mutandis 10(2): 263-267.

Vidal Claramonte, M. Carmen África (2009) 'A vueltas con la traducción del siglo XXI', MonTI. Monográficas de Traducción e interpretación (1): 49-58.

\section{RÉSUMEN}

En el presente artículo se ofrece una comparación entre varios conceptos que vuelven a aparecer en las actuales obras de los autores hispanohablantes y las teorías del traductólogo checo Jiří Levý. Un breve esbozo de la evolución de la investigación en el campo de la traductología en España sirve como punto de partida para explicar la relativamente poca divulgación de las teorías de Jiří Levý entre los autores hispánicos, en comparación con las autoridades de otras áreas lingüísticas. Como punto de partida se han tomado los conceptos de los llamados anisomorfismos de la traducción y del "punto de partida del trabajo del traductor", que se han comparado con posibles analogías de los trabajos de Jiŕí Levý (la traducción como proceso de decisiones, el patrón), perspectiva que ha revelado un mayor dinamismo y complejidad de los conceptos del autor checo, a pesar de haber sido definidos hace más de medio siglo.

prof. PhDr. Jana Králová, CSc. Ústav translatologie, Filozofická fakulta Univerzity Karlovy, Praha jana.kralova@ff.cuni.cz 